\title{
建築物の言語描写の擬態語表現における建築の即物の様相 MATERIAL ASPECTS OF ARCHITECTURE AND MIMETIC WORD EXPRESSION IN TEXT DESCRIPTION OF BUILDINGS
}

\author{
篠原寛之*, 北川啓介**, 田原聖*** \\ Hiroyuki SHINOHARA, Keisuke KITAGAWA and Sho TAHARA
}

\begin{abstract}
The text description of building by mimetic words is a frequently used form of communication for Japanese architects to express their building design intent. The mimetic words describe a material building vividly and sensually as if it gains its own life and express connotative meaning of architecture that the architect imbues through the depicted building posture and gesture. The objective of this paper is to identify material aspects of architecture rhetorically characterized by mimetic word expressions used in the explanation of works of architecture through the text description of buildings in a monthly Japanese architecture magazine, Shinkenchiku. The result of this paper typifies 24 aspects of material architecture expressed in mimetic word descriptions which reflect architects' thinking towards bodily involved architecture of everyday.
\end{abstract}

Keywords : Mimetic Word, Material Constituent of Architecture, Text Description, Sound-Symbolic Meaning, Subject, Regulating Verb 擬態語, 即物, 言語描写, 基本義, 主体, 規定語

\section{1. はじめに}

設計者による建築物の言語描写において，「しっとり潤った木肌」 や「じっとりと湿った空間」と建築物が描写される場合, いずれも 湿度に関する触覚的な表現であるが，「しっとり」と「じっとり」と では, 微妙な湿度感の違いとそれに付帯するイメージや印象を読み 手に与える。擬態語を用いたこれらの表現により, 前者は水分が程 よく行き渡った木質表面の柔らかい印象を与え, その素材感による 優しく居心地が良い様などを想起させるが，後者は空気中に水分が 過剩に含まれる湿りきった室環境のべたついた印象を与え, そのよ うな環境にある空間は不快で居心地が悪い様などを想起させる。

また，建築物と外部環境の関係を視覚描写した「外観はしっとり と村落にとけ込む」という表現では, 擬態語を用いることであたか も水を弾くことなく程よく保水しているかのように建築物の外観を 捉えている。そのような外観は周辺の風景と馴染むように一体とな り, より身体に訴えかけ, 印象深く, また, 落ち着いた風情や安ら ぎといった情緒なども想起させる情景となっている。

このように, 設計者は僅かな色合いや素材感の違い, 人や自然現 象の移ろいによる空間様相の変化, 周辺と建築物の相対的な成立状 況など, 差異のある事物や複雑に絡みあった事象を擬態語により描 写する。擬態語は, 一般的な概念語と異なり, 参照するものごとの
動きや状態を音象徴的注1) に再現し, 人々の身体感覚に寄り添った, より共感しやすい空間認識を促す。したがって,イメージ喚起性が 強く物事の複合的意味のニュアンスを伝達しやすいため, 設計者が 自身の建築物を解説する際に，意図する建築物の性質，概念的に漠 然とした未分化なイメージ, 現象の様相から受ける印象や価值判断 などを直接的に表現することができる。

以上のことから，擬態語は，物性に即した佇まいや動きの様相を 建築物自らがもちあわせているかのように客観的に描き出し，感覚 的なフィルターを通して，あたかも事物や事象の内面的な性格が空 間の様相となって現れてくるような強い印象を読み手に与えること で，設計者が建築空間に込めた主観的な意図や思いを暗示する。

本稿では，建築空間を構成する建築物自体，建築構成部位，物質 的現象などの知覚可能な要素を即物と定義し, 擬態語表現により描 写される建築の即物の様相を論考する。そのため, 第 $2 \sim 5$ 章で既 往の研究や研究の対象, 研究の方法を整理した後, 第 6 章では擬態 語と即物の関係を明らかにする。次に，第 7 章では擬態語と即物の 建築空間内での状態や動きの関係を明らかにする。そして第 8 章で 擬態語表現による建築の即物の様相を論考し, 第 9 章で設計者の主 観的な感覚や未分化なイメージに基づく空間認識や設計過程におけ る思考を捉え, 結論に至る。

\footnotetext{
* 名古屋工業大学大学院工学研究科 博士後期課程 $\cdot$ 修士 (建築)

Doctor Course Student, Graduate School of Engineering, Nagoya Institute of Technology, M. Arch

** 名古屋工業大学大学院つくり領域 准教授·博士 (工学)

*** 住友林業(株) 修士 (工学)
Assoc. Prof., Tsukuri College, Graduate School of Engineering, Nagoya Institute of Technology, Dr. Eng.

Sumitomo Forestry Co., Ltd., M. Eng.
} 


\section{2. 既往の研究}

空間や建築・都市を構成する要素を表現する擬態語に関する研究 として，デワンカー・バートらによる空間を表現する擬態語に関す る研究 ${ }^{1)}$, 秋田剛らの擬態語や擬音語を用いた環境表現に関する研究 2) が挙げられる。ひとつ目は, 空間の認識条件となる物体の大きさや 形状，状態を表す意味をもつ擬態語を，擬態語を取り扱った辞典か ら選定し, 研究対象とした擬態語から想起されるイメージを, SD 法 を用いて設計経験者と非経験者とで比較分析することで, 設計経験 者が，擬態語のもつ複数のイメージを区別して認識することを明ら かにしている。ふたつ目は，擬態語を用いた光，音，風などの環境 要素の表現が，人々に強弱などの異なる環境条件を想起させるのに 有効であることを，アンケート形式の調查により明らかにしている。 本研究は, 建築領域の中で言語描写における擬態語の感覚的な伝達 能力に係わる知見を示している点でこれらふたつの研究と同調する が，空間一般や特定の環境要素に関して扱うのではなく，建築空間 を構成する事象全般に関して扱う点, また，心理実験やアンケート といった定量的な分析を行うのではなく，擬態語の描写内容を擬態 語とその周辺の語句の語義に着目し，分析することによって設計者 が建築物に込めた意味を考察する点において異なる立場をとるもの である。

本稿では，設計者が自身による建築物を解説した文中で，建築空 間を言語描写する際に用いた擬態語表現に着目している。そして, 建築空間を構成する知覚可能な要素を示す語句，建築構成要素の動 きや状態を示す語句，建築構成要素のより子細な様相を特定する擬 態語表現の意味の相関を分析することにより，建築空間に複合され た印象を捉え，擬態語により言語描写される際の，建築物の様相を 明らかにする。

\section{3. 研究の対象}

本研究では，擬態語表現における建築空間を構成する事象の様相 を考察する上で, 研究対象を実際の建築空間の言語描写がされてい る言説とした。そこで, 時代に対して文献の量に偏りがなく, 設計 者の言説として十分な資料を得ることができる点を考慮して, 現代 まで継続的に建築作品及びその解説文を掲載している建築専門誌『新 建築』3) を研究資料とする。本稿では，執筆者の文責が明らかである 1950 年から 2010 年までを対象期間とし，掲載された設計者自身の 作品に対する解説文の中で, 建築空間を構成する事物及び現象の動 きや状態が擬態語によって描写された 538 の建築物における延べ 659 事例を研究対象とする。

\section{4. 研究の方法}

本稿における擬態語表現とは，空間を構成する事物や物質的現象が 擬態語と動作や状態を表す動詞によって描写されている表現とする。

擬態語の語義は，擬態語を取り巻く語句や文脈によって特定され るため, 研究対象とした記述から, 擬態語表現が用いられている文 章をキーコンテクスト注2) として抽出し, 擬態語により修飾され, 意 味付けされる建築物や構成部位，人などの建築空間を構成する物体 だけでなく水や光，時間などの物質的現象なども含む，建築空間を 構成する知覚可能な要素を主体，擬態語のもつ基本的な意味合いの カテゴリーと音韻注 3) による程度の大小の組み合わせにより決定さ
『新建築』1991年3月号 p.270

ウイングハウス（大阪営林局箕面自然休養林休咊舎）／新田正樹建築設計工房

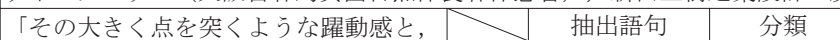
それでいて，なんとなく清楚な浘たすき基本義ししとりと【湿潤度(小)】

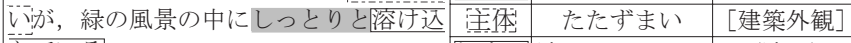
んでいる. 规定語溶け込んでいる

\section{図 1 基本義・主体・規定語の抽出例}

れる擬態語の語義を基本義，擬態語と修飾関係にあり，かつ主体と 主述の関係にある主体の動作や状態を表す動詞句を規定語と定義し, これらの語句を抽出し，意味内容を考慮し，分類する（図 1 )。カテ ゴリー分けを行うことにより，日本語表記における漢字表現，平仮 名表現，送り仮名の差異を解消寸る。さらに，基本義と主体，基本 義と規定語のそれぞれの組み合わせのコレスポンデンス分析注4)を 行い, 得られた散布図から分類間の相関の傾向を整理する。その後, 双方の傾向の組み合わせを, 記述内容を考慮しながら, 比較考察す ることにより，意味のまとまりを捉え，建築物の言語描写の擬態語 表現における建築の即物の様相を明らかにする。

\section{5. 抽出項目の分類}

基本義は, 主体と組み合わさることで, 事象の性質や性状を特定し,

\section{表 1 基本義の分類}

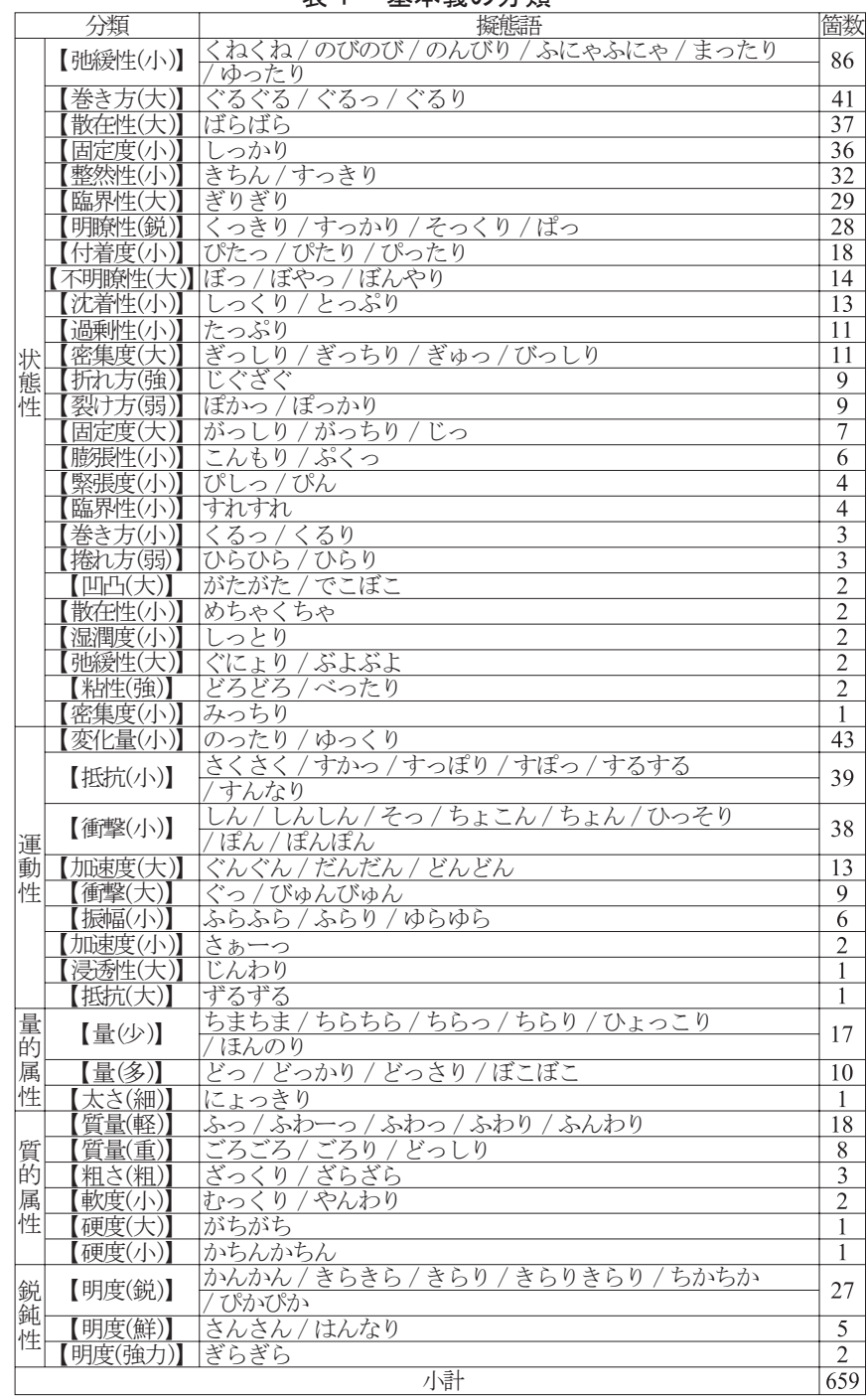

※擬態語が複数の描写主体を描写する場合は各描写主体を区別して数え，総数を箇数に記す。 
表 2 主体の分類

\begin{tabular}{|c|c|c|c|}
\hline 刀賛 & 分類の説明 & & \\
\hline [建築全体] & 建築物の全体 & 建物 / 美術館 & \\
\hline [人] & 子供や大人を含む全ての人間 & 子供/客 & \\
\hline [室空間] & 建築物の中の区切られた単位空間 & 温室/葠室 & 42 \\
\hline [壁] & 空間を分離している垂直の構造物 & 壁/外壁/壁面 & 40 \\
\hline [L屋根] & 外部に面して空間の上部を覆うもの & 屋根/陸屋根 & 32 \\
\hline [調度品] & 日常什器や家具などの道具 & カウンター/本 & 31 \\
\hline [光] & 太陽や照明などの発光体からでる光線 & 光 $/$ 太陽 /照明 & 26 \\
\hline リ゙オリューム & 塊としての建築物やその大きさ & ボリューム & 25 \\
\hline [動線空間] & 廊下や通路など，移動を目的とした空間 & 廊下/階段 & 23 \\
\hline [建築外観] & 建築物を外側からみた様子 & ファサード/外観 & 21 \\
\hline [領域] & 角途や事物がかかわりをもつ範用 & 場所 / 空際 & 19 \\
\hline [開口部] & 採光や通風の為に建築物の切り抜かれた部分 & 開口/空 & 17 \\
\hline [外部空間] & 機能に関わらず，建築物の外部 & 中庭 / 広場 & 17 \\
\hline [構造] & 建築物の骨格となるもの & 構造 / 木造架構 & 17 \\
\hline [周辺環境 & 敷地周辺の自然物及び建物群 & 周辺環境/隣家 & \\
\hline [材料 $]$ & 建築物を構成する素材の総称 & 材料/素材 & 15 \\
\hline [ディテール] & 複数の部材が接合された部分 & 接合部/ディデール & 14 \\
\hline [内部空間 $]$ & 機能に関わらず，建築物の内部 & 内部空間 & 14 \\
\hline$[$ 水] & 状態を問わず水素と酸素の化合物 & 水/しずく & 14 \\
\hline [風暻] & 景色などある地点における可視的な場の様子 & 風景/景観 & 12 \\
\hline [植物] & 樹木や草木など場所を固定して生きるもの & ケヤキ/マツ & 10 \\
\hline 平面形] & 平面計画の結果生まれた平面形羾 & 平面形/プラン & 10 \\
\hline [金属] & 建築材料としての金属 & コールテン鋼 & 9 \\
\hline 类木] & 建築材料として加工された木材 & 材 / 焼杉 & \\
\hline [䓃彩] & 彩りや色合いなど色に関わるもの & 色彩/青 & 9 \\
\hline [天井] & 室内空間の上限を構成する面 & 天井 & 9 \\
\hline 輪郭] & 視覚により捉えられる物体の外形 & 輪郭/シルエット & \\
\hline [空気 & 空間内の無職透明な混合気体及びその流れ & 空気/風 & 8 \\
\hline [地形] & 地面の形態的特徵 & 平地/坂 & 7 \\
\hline [床] & 室内空間の下限を構成する面 & 床/スラブ & 6 \\
\hline [柱] & 建築物を支える垂直の部材 & 柱列/柱 & \\
\hline [石] & 鉱物のかたまり & 大理石の小片/石 & 4 \\
\hline [時間] & 時の流れの中の一定の長さ & 時間/時 & 4 \\
\hline$[$ 軒] & 屋根の下端で，建築の外壁から張り出した部分 & 軒 & 4 \\
\hline [陰影] & 光の当たらない暗い 部分 & $\begin{array}{c}\text { 影 } \\
\end{array}$ & 3 \\
\hline ガラス] & 建築部材としてのガラス & ガラス/ガラス箱 & 3 \\
\hline [敷地] & 建築物の占める一定区画の土地 & 敷地/土地 & 2 \\
\hline [自然] & 山などの人間の手が加わっていないもの & 山/谷間 & 2 \\
\hline [寸法 $]$ & 設計者により定められた部位の位置 & 窓高さ/天井高 & 2 \\
\hline 而侯材] & 外的環境を遮断し内部環境を保つ材料 & 外防水 / 断熱材 & 2 \\
\hline [熱] & 物体の粒子の運動により生まれるエネルギー & 爇/太陽熱 & 2 \\
\hline [梁] & 建築物を支える水平の部材 & רו & 2 \\
\hline [塀] & 建築物や敷地の境界に設ける囲い & 木柵/土塁 & 2 \\
\hline \\
\hline
\end{tabular}

表 3 規定語の分類

\begin{tabular}{|c|c|c|c|c|c|}
\hline & 記述例 & 箇数 & 分類 & 記述例 & \\
\hline 容〉 & ぐるつと包み込む゙.. & 58 & 〈浮遊〉 & 「ふわーつ」と浮かせる… & 8 \\
\hline & ゆっくりとした視線をもつ & 38 & 〈分解〉 & バラバラに分化させで... & \\
\hline & 温室はきちんとூつくで... & 34 & 〈使用〉 & たつぷり便う・... & \\
\hline 置〉 & きちんと毃置する゙・. & 31 & $\langle\langle\dot{1}$ 立〉 & ばらばらに自立し… & 7 \\
\hline & ぐるぐるy奥まっていく $\cdots$ & 29 & $\langle$ 〈対抗〉 & キラキラ反射し・・ & 7 \\
\hline & ゆっくりと風か流机る。... & 27 & $\langle$ 方張 $\rangle$ & ぴしっと涱ったり... & \\
\hline & そっと佇古… & 26 & 〈接近〉 & 寸れすれにはわせる… & \\
\hline & キラキラ光っで... & 26 & 《娛楽〉 & ゆっくりプレーを楽しめる゙... & 5 \\
\hline & しっくり溶け合って… & 19 & 〈縮小〉 & ぎりぎりに切りつめられた・.. & \\
\hline & がらり変化し･. & 19 & 〈成熟〉 & のびのびと発育していく... & \\
\hline & スッポリ開ける.... & 18 & $\langle$ 切取 $\rangle$ & きっちりと切り取られだ.. & 5 \\
\hline & ぎりぎりの厸衡を保っで... & 16 & 〈滞在〉 & のんびり と過ごせる゙... & \\
\hline & のびのびとひろがる... & 14 & 〈適合〉 & ピッタリあっだ... & 5 \\
\hline & ぐるぐる走り回ったり $\ldots$ & 14 & 〈安息〉 & すっかり落ち着いてきている... & 4 \\
\hline & ギリギリまで押し出す、.. & 13 & 受容〉 & しっかりと受け止め゙.. & 4 \\
\hline & 壁をぐるぐるに巻き|... & 11 & 〈周回〉 & ぐるぐる回っで... & 4 \\
\hline 喿〉 & たっぷりととる゙... & 11 & 〈静寂〉 & ひらそりと静まりかえり & 4 \\
\hline & ひっそりとたてられる. & 11 & 整理〉 & きちんと整理されだ... & 4 \\
\hline & ヒラリと舞い、降りた・・. & 11 & 〈騒然〉 & しつくりと落着かない... & \\
\hline & ぐるぐる登っていく... & 11 & 〈排出〉 & ゆっくりと悲出される゙... & 4 \\
\hline 曲〉 & ゆっくり历ーブしで.. & 11 & 〈閉鎖〉 & しっかりと閉じられ... & 4 \\
\hline & ザラザラに仕上げで・. & 10 & 隠蔽〉 & すっかり[隠蔽する・... & 3 \\
\hline & ぎりぎりの絡み合い.・. & 10 & 〈伸張〉 & ギリギリまて伸びている. & 3 \\
\hline 続〉 & くねくねと連続した空間は & 10 & 〈生活〉 & バラバラに泩活し・. & 3 \\
\hline & ギッシリ䚾った訜后街・.. & 9 & 〈廭層〉 & ぴちたりり董なっだ... & 3 \\
\hline & ぐるっとレイアウトした... & 9 & $\langle\langle\bar{t}$ & すっきりとしたデサイとした & 2 \\
\hline 成〉 & ジグザグに構成されている・.. & 8 & 〈後退〉 & ジグザグと・セットバックに・.. & 2 \\
\hline & こんこんと湧き出る… & 8 & 雀合〉 & チマチマと集まっで... & 2 \\
\hline & しっくり抑えている & 8 & & どんどん実体を失って… & 2 \\
\hline & 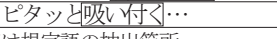 & 8 & & 小計 & 65 \\
\hline
\end{tabular}

※下線部は規定語の抽出筒所

※擬態語が複数の描写主体を描写する場合は各描写主体を区別して数え, 総数を箇数に記す。

※記述例の引用元『新建築』(左上から右下に) p.129,2009.9/p.160,1980.10/p.160,2009.5/p.158, 1998.1/p.76,2010.7/p.63,2007.3/p.169,1999.6/p.263,1987.12/p.240,1977.2/p.160,1980.10/p.121,2003. 5/p.193,1997.9/p.172,1971.4/p.199,1979.9/p.229,1974.4/p.226,1983.4/p.185,2004.12/p.217,1971.12/p 152,1997.4/p.185,2004.6/p.82,2008.12/p.230,1977.2/p.188,1983.12/p.71,2003.8/p.40,1957.12/p.88,20 07.3/p.149,1983.9/p.232,1987.8/p.157,1952.4/p.158,1983.10/p.222,1999.3/p.216,1977.6/p.10,1957.2/p $.184,1979.10 /$ p.278,1991.7/p.117,2009.3/p.167,1975.4/p.35,1961.8/p.262,1976.2/p.267,1989.3/p.181,1 994.10/p.175,2002.3/p.265,1993.3/p.126,1962.10/p.109,2003.7/p.173,1987.2/p.240,1985.9/p.310,1984 $.8 /$ p.16,1950.10/p.126,2007.4/p.211,1980.4/p.152,1977.4/p.192,1952.4/p.45,1961.9/p.97,1999.7/p.118, 2004.10/p.201,1992.12/p.254,1980.8/p.105,2004.1
擬態語表現により描写される建築空間の一側面を決定づけるもので ある。擬態語は, 音象徴を用いて事象の動きや状態を表現する語句 であり，音韻によって語義が大別されるため，音韻を考慮した上で, 物体間の関係を表す状態性, 物体の運動の様子を表す運動性, 物体 の量や大きさを表す量的属性，物体の性質を表す質的属性，物体の 発する刺激の鋭さを表す鋭鈍性に着目することで基本義のカテゴリ 一を決定する。さらに，有声・無声といった特徵に着目することで 程度の大小も考慮し，47 種のカテゴリーに分類した（表 1 ）。

主体は，擬態語と組み合わさることで設計者が着目した建築空間 の一側面を表すものである。抽出した語句の意味内容を判断しなが ら，規模や建築空間における役割といった観点から，43 種のカテゴ リーに分類した。（表 2)

規定語は，擬態語と組夕合わさることで，擬態語が示す音象徵か らくる語義を補完し, 擬態語の意味の属性を決定づけ，建築空間内 での主体の動作や状態を特定する語句である。抽出した語の記述中 での意味内容を判断しながら, 59 種のカテゴリーに分類した（表 3 ）。

\section{6. 基本義と主体のコレスポンデンス分析}

基本義と主体をクロス集計した結果，組み合わせ総数として延心゙ 659 の組み合わせが得られた。これをもとにコレスポンデンス分析を 行い，基本義と主体の関係の強さを散布図上の距離に転換して模式 化することで傾向を整理した（図 2 ）。そして，得られた散布図をゾ 一ニングし, 原点からの距離に比例して比重を置いて解釈した結果, 潜在性による環境計画事象 169 事例, 空間を演出する流動体 77 事例, 拡縮により捉えられる肌理 64 事例, 形状による建築の主要部位の振 る舞い 94 事例の 4 つの傾向に整理することができた。以下に，それ らの傾向を構成する組み合わせとそれぞれの傾向の特徴について述 ベる。

潜在性による環境計画事象では，[植物］は【膨張性（小)】など と強い相関を示し，「こんもり繁った庭のケヤキやモミジ」注5)の描 写のように, 人の手が加わっていない自然物の様子を表現している。 また [人］は【巻き方（大)】などと強い相関を示し，「子供たちは

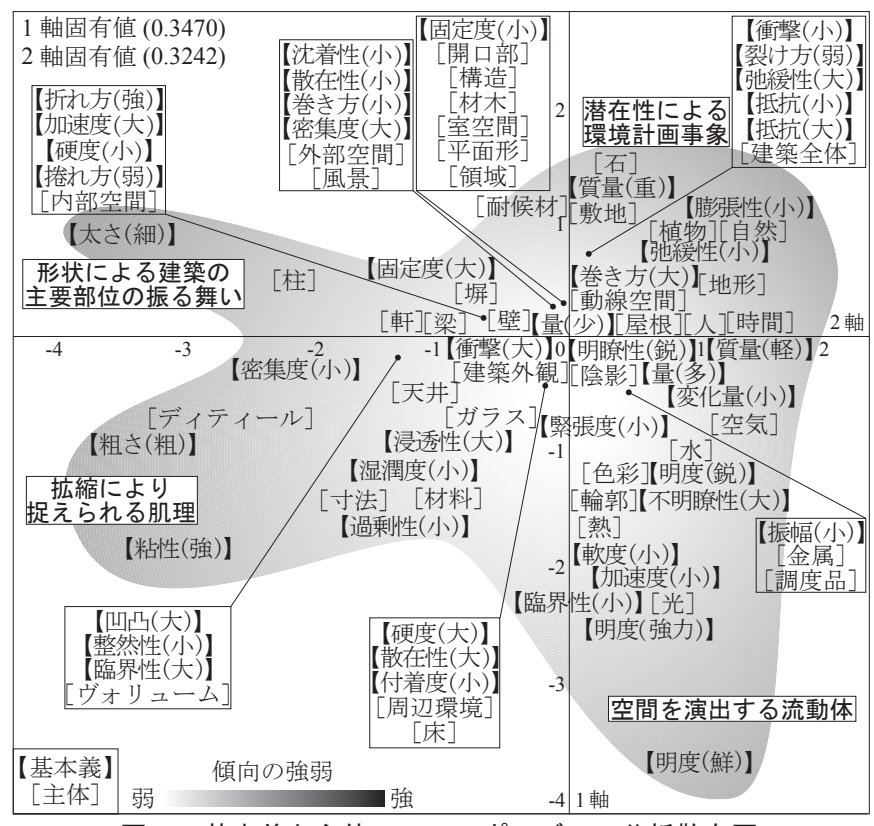

図 2 基本義と主体のコレスポンデンス分析散布図 
ぐるぐる走り回ったり」注6) の描写のように, 束縛されない子供の自 由な動きを表現している。以上より，これらは環境を構成する自然 物や人に潜在する性質を顕在化させることで, 快適で生き生きとし た空間の様相を表現しているといえる。

空間を演出する流動体では，［光］は【明度（鮮)】などと強い相 関を示し，「光は四方からさんさんと降り注ぎ」注7)などの描写のよ うに, 鮮明な光線の情景を捉えており, 光量が多く鮮やかな光の様 態を表現している。また［熱］は【変化量（小）】などと強く相関を 示し，「熱は外壁のスリットからゆっくり排出される」注8) の描写の ように，不定形な流動体を捉えており，触覚への影響を考慮した熱 の流量が調整されている様子を表現している。以上より，これらは 空間内に存在し体感される流動体の緩急を調整することで，微細な 空間の動きを印象的に表現しているといえる。

拡縮により捉えられる肌理では, [ヴォリューム] は【臨界性 (大)】 などと強い相関を示し，「周囲の建物は隣地境界ギリギリに建ってお り」注9) の描写のように, 計画された建築物が高密度な都市スケール の一部分に位置付けられることを表現している。また [ディテール] は【粗さ (粗)】などと強い相関を示し,「(タイル貼りや石貼りは) 手作りの温もりが伝わるように，ザックリと仕上げる」注 10) の描写 のように，建築物の表面に焦点を当てた際，顕在化する素材表面の 粗さを表現している。以上より，これらは巨視的な視点から微視的 な視点までの縮尺を越えた認知により事物の状態を捉えることで, 建築物の存在感を表現しているといえる。

形状による建築の主要部位の振る舞いでは，[柱］は【太さ（細）】 などと強い相関を示し，「地中からニョッキリと立ち上がった片持の コンクリート列柱」注11) の描写のように，自身のプロポーションを 細く長く整え端正に直立寸る佇まいを表現している。また，[建築外 観】は【硬度（大)】などと強い相関を示し，「セキュリティの要請 でガチガチに角質化してしまった建築の皮膚」注12) の描写のように, 壁の極端な硬さによる表情で建築物を内向させる身振りを表現して いる。以上より, これらは建築を構成する主要部位の形状や質感に よって, 建築に動的な様相を付加することで生命をもたない建築に 表情をもたせ，性格付けをしているといえる。

\section{7. 基本義と規定語のコレスポンデンス分析}

基本義と規定語をクロス集計した結果，組み合わせ総数として延 べ 659 の組み合わせが得られた。これをもとにコレスポンデンス分 析を行い，基本義と規定語の関係の強さを散布図上の距離に転換し て模式化することで, 傾向を整理した（図 3 )。そして, 得られた散 布図をゾーニングし，原点からの距離に比例して比重を置いて解釈 した結果, 主体と規定語の組み合わせは, 微調整された動向 112 事例, 定常状態の逸脱 78 事例，形成される取合いの差異 183 事例，鋭鈍に より顕在化する相関 94 事例の 4 つの傾向として捉えることができた。 以下に，それらの傾向を構成する組み合わせとそれぞれの傾向の特 徵について述べる。

微調整された動向では，〈回転〉は【巻き方（大)】などと強い相 関を示し,「長さ $300 \mathrm{~m}$ の壁をぐるぐるに巻き」注13) の描写のように, 大きく何重にも巻かれることで, 力強い様子を表現している。また〈回 転〉は【巻き方 (小)】とも強い相関を示し,「風のあるとき風車が クルクル回り」注14) の描写のように，小回りに回転する動きから軽

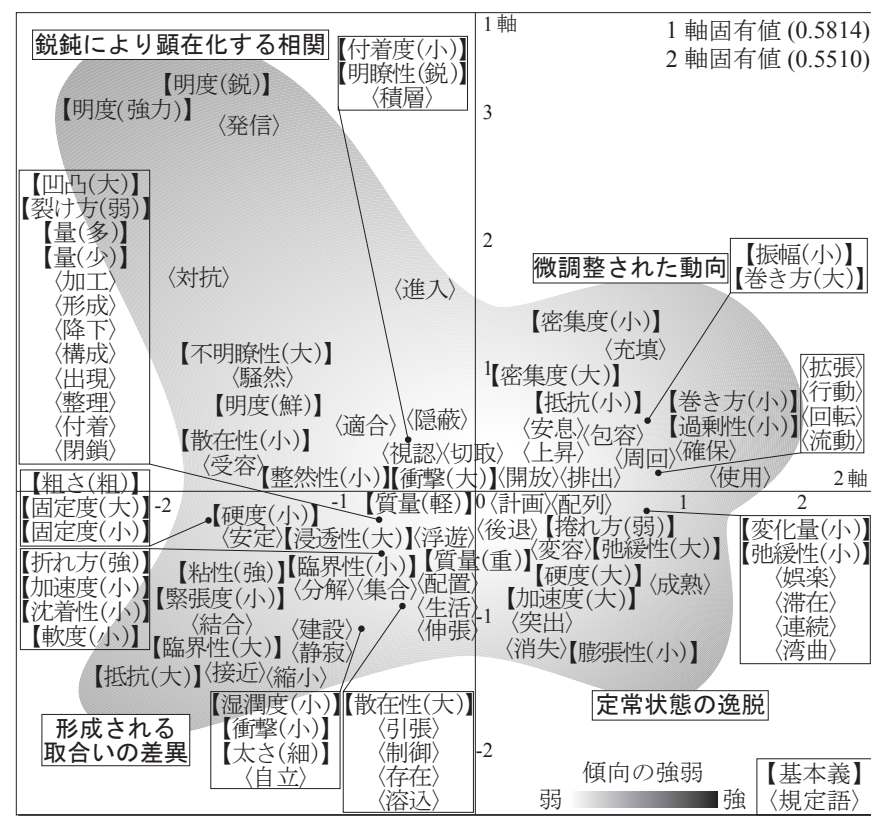

図 3 基本義と規定語のコレスポンデンス分析散布図

快さが付加され主体のもつ趣きを表現している。以上より，これら は方向性のある動きに対して微妙な程度の違いを認識することで主 体の存在感を暗示し, 情緒を付与しているといえる。

定常状態の逸脱では，〈突出〉は【膨張性（小)】などと強い相関 を示し，「ぷくっと押し出されたかたちの階段室を，隣の住戸が日常 的に親しめる風景となるように」注15) の描写のように，自身の機能 性を保ったまま主体が環境の一部となるべく適応している様子を表 現している。また〈変容〉は【弛緩性（小）】などと強い相関を示し， 「温度によって形状がフニャフニャと変わる建築」注16) の描写のよう に，主体と主体を取り巻く環境の関係が偏り，主体が受動的に存在 している様子を表現している。以上より，これらは事象同士の関係 が安定しておらず不均衡である状況を形成することにより，他律的 に変容する建築の様相を表現しているといえる。

形成される取合いの差異では，〈接近〉は【臨界性（大)】などと 強い相関を示し，「ぎりぎりの均衡を保って境界面が確定される」法 17)の描写のように, 均衡した事象が共存している様子を表現してい る。また〈存在〉は【衝撃（小）】などと強い相関を示し，「(大自然 の中に）ひっそりとたたずむ建築」注18) の描写のように，主体の存 在感を抑え対象と一体化する様子を表現している。以上より，これ らは事象間の境界で発生する取り合いの微細な差異により, 建築を 構成する事象同士の繊細な関係性を表現しているといえる。

鋭鈍により顕在化する相関では, 〈発信〉は【明度（鋭）】などと 強い相関を示し，「樹木の間からガラスの屋根だけがキラキラ光って 見える」注 19) の描写のように, 強い明るさを帯びた主体の存在が周辺 から突出している様子を表現している。また〈進入〉は【不明瞭性 （大）】などと強い相関を示し，「半透明のスクリーンには，時間や天 候によって，空の青や樹々の緑や岩壁の黒がぼんやりと映り込む」油 20) の描写のように，主体である前景と置かれる背景間で一方が他方 に取り込まれることにより曖昧に融合している様子を表現している。 以上より，これらは主体が鋭鈍性を帯びた挙動を起こすことで，主 体と主体を取り巻く事象の間に序列が形成され，ふたつの事象の相 関を顕在化しているといえる。 


\section{8. 基本義・主体・規定語からみる建築の即物の様相の類型}

本稿では，擬態語表現における建築の即物の様相を決定づける 3 つの要素として主体, 基本義, 規定語を位置づけている。これらの 要素間のコレスポンデンス分析散布図から得られたそれぞれの傾向 を重㸚合わせ，語義により類型を導出し，擬態語表現における建築 の即物の様相を考察する。そのため，キーコンテクストに含まれる 主体, 基本義, 規定語の組合せを, 図 2,3 に現れた傾向の違いと その強弱を判断の手がかりとして全ての事例を比較考察し, 原文の 記述内容も考慮した上でいくつかの意味のまとまりとして位置づけ た。その上で，意味のまとまりの枠組みをもっとも端的に表せるよ う, 図 2,3 に現れた傾向の違いを軸として, 二次元上に位置づける こととする。意味のまとまりを導出する際に，複数の軸をまたいで まとめることのできる枠組みを捉えることができた注21)。これらの枠 組みはひとつの要素で意味づけられる傾向が強く, その他の要素か ら意味づけられる傾向が弱い枠組みであるといえる。また，図 2,3 で得られた傾向の違いによる軸は独立した評価軸ではあるが，それ ぞれの傾向を構成するのに大きく起因している図 2,3 における周辺 部の要素同士の組合せ以外は明確に区切ることができないため，そ れぞれの傾向の違いによる軸の概ねの領域を点線によって示し, 縦 軸，横軸のそれぞれの傾向が一連の軸であることを矢印を用い，傾 向の強弱と共に示している。上記のことを考慮した上で意味のまと まりを位置づけた結果，擬態語表現における建築の即物の様相とし て少なくとも $\mathrm{A} \sim \mathrm{X}$ の 24 種の類型を導出した注22) (図 4)。以下に, 各類型の考察を述べる。

A は,建築物が方向性や勢いのある運動性を示すことにより，万物 が逃れられない重力から解放されている様子を表現しているといえ る。 $\mathrm{B}$ は，包みこんでいる範囲の大きさにより，包囲包含関係を明 確化し, 空間を構成する要素の間に序列を見出しているといえる。C は, 微細な挙動や変質により, 身の回りに存在する事象が変化してい ることを実感させているといえる。D は, 抵抗が少なく全体が包まれ ることにより，建築部位や素材が空間を包んでいる様子に違和感がな く, 人に安心感を感じさせているといえる。 E は, 集合体を構成する 要素の間隔が詰まっている様子や小さくまとまっている様子により， 身体単位から空間単位までの集合体が密に集まり，かつ個々の状態を 確実に認識することで, 多様な要素の集合体である建築の存在を強く 感じさせているといえる。F は, 鋭く折れた角が連続していることに より,壁が細かく分節され，空間に動きを演出しているといえる。G は, 硬さをもつ状態が形成されることにより,建築物の表層が硬さを 帯びており，他者を寄せ付けない印象を与えているといえる。Hは， 動きの変化が少なく安定していることにより,静穏な人の活動に余裕 が生まれ，落着きのある空間をもたらしているといえる。I は, 必要 量より少し多い量を考慮していることで, 量や規模に若干の余裕をも たせ,機能性の向上した空間を形成しているといえる。Jは,膨らん で盛り上がった形状が内部の人の活動を示しており, 外観が内在する 活動や現象を暗示しているといえる。Kは，建築物自身もしくは建築 構成要素を弛緩させ, 軟化させることで,他者を受け容れやすい状態 が形成されているといえる。L は, 微細かつ軽く流れている様子を示 し, 室内気候が微細に移ろい, 快適な環境を形成しているといえる。 M は,整った状態が形成される様子を示し, 単純化された細部により , 美しい構築物としての建築が構成されているといえる。 $\mathrm{N}$ は, 限界
まで近づいている様子を示し, 境界に構成要素が限りなく近付くこと で, 境界が視覚的に輪郭付けられているといえる。O は, 表面が粗く 仕上げられている様子を示し, 細部を美しく整えるのではなく, 粗い 状態に仕上げることで触覚的に印象付けているといえる。Pは，一体 化して落ち着いている様子を示し, 建築物が周囲とほどよく融合し， 落ち着いた情景を形成しているといえる。Q は, 確固たる秩序立ての ある状態を形成している様子を示し, 細部に不備がないようにするこ とで, 建築の機能を最大限発揮しているといえる。 $\mathrm{R}$ は, 個々が分散 し, 独立している様子を示し, 建築構成部位が独立して並置されるこ とにより，建築を構成する部位の体系を顕在化しているといえる。 $\mathrm{S}$ は,十分に結びつき安定している様子を示し, 建築物が地域社会に根 付いているといえる。 $\mathrm{T}$ は, 周囲への影響を最小限に抑え, 同化して いる様子を示し, 建築物が自らの存在を希薄化し, 主張しないように 周囲と一体化しているといえる。U は, 力強く存在を示している様子 を示し,強い存在感を示す自然物により空間が規定されているといえ る。Vは, 鋭く光り輝いている様子を示し, 建築物が自然現象を活用 して自らの存在を主張しているといえる。W は, 過度な付着を回避 している様子を示し, 細部と全体が一体化する状態に対して, 付着 具合により, 複合体を構成する事物間の違和感を調整しているとい える。Xは，他者を介することで明確に認識できなくなる様子を示し , 視覚情報が明瞭に認識されないために抽象化され, 色彩のみにより 光景が形成されているといえる。

\section{9. 結論}

本稿では，設計者が自身の建築物を言語描写する際に擬態語を用 いて表現した建築の即物の様相について，基本義，主体，規定語の 組み合わせから考察を行った。まず，基本義と主体のカテゴリーを 全体の用法として関連性を考察した結果, 潜在性による環境計画事 象，空間を演出する流動体，拡縮により捉えられる肌理，形状によ る建築の主要部位の振る舞いの 4 つの傾向に整理することができた。 また，基本義と規定語においても同様に，微調整された動向，定常 状態の逸脱，形成される取合いの差異，鋭鈍により顕在化する相関 の 4 つの傾向に整理することができた。これらを踏まえて, 基本義, 主体, 規定語の特徴を重数合わせることによって考察した結果, 少 なくとも 24 種の擬態語表現における建築の即物の様相が認められた。 これら 24 種の類型は基本義, 主体, 規定語により意味づけられてい るが，さらにその性質や役割により特徵づけることができる。

A， C, H，L，U は，動かないことを前提としている建築物に対して， 運動性を示寸擬態語を用いることで時間の経過や場の移動，あるい は，光や空気などの環境構成要素の実存上の動きによる空間の変容 の様子を捉えている。これらは，存在と消滅の間を移ろう建築の現 象的な諸相を表現している。また，E，I，Q，R，W は，密集する事 物の存在感, 材料を余分に用いることによる空間の付加価值, 緊結 された部材の機能性，付着した事物の異物感などを捉えている。こ れらは，建築物を構成する事物の物量や密集度，結合度など全体を 構成する要素を局所的に強調することで複合的な性質を帯びた空間 の様相を表現している。D，F，G，J，K，M，Oは，身体感覚を喚 起する子細な建築の表層, 人の動作や生活を示すことで空間の利用 形態を想起させ強調された建築空間とその場所性，余裕のある空間 が誘発する安堵の感情, 装飾性の有無やプロポーションによる美観, 


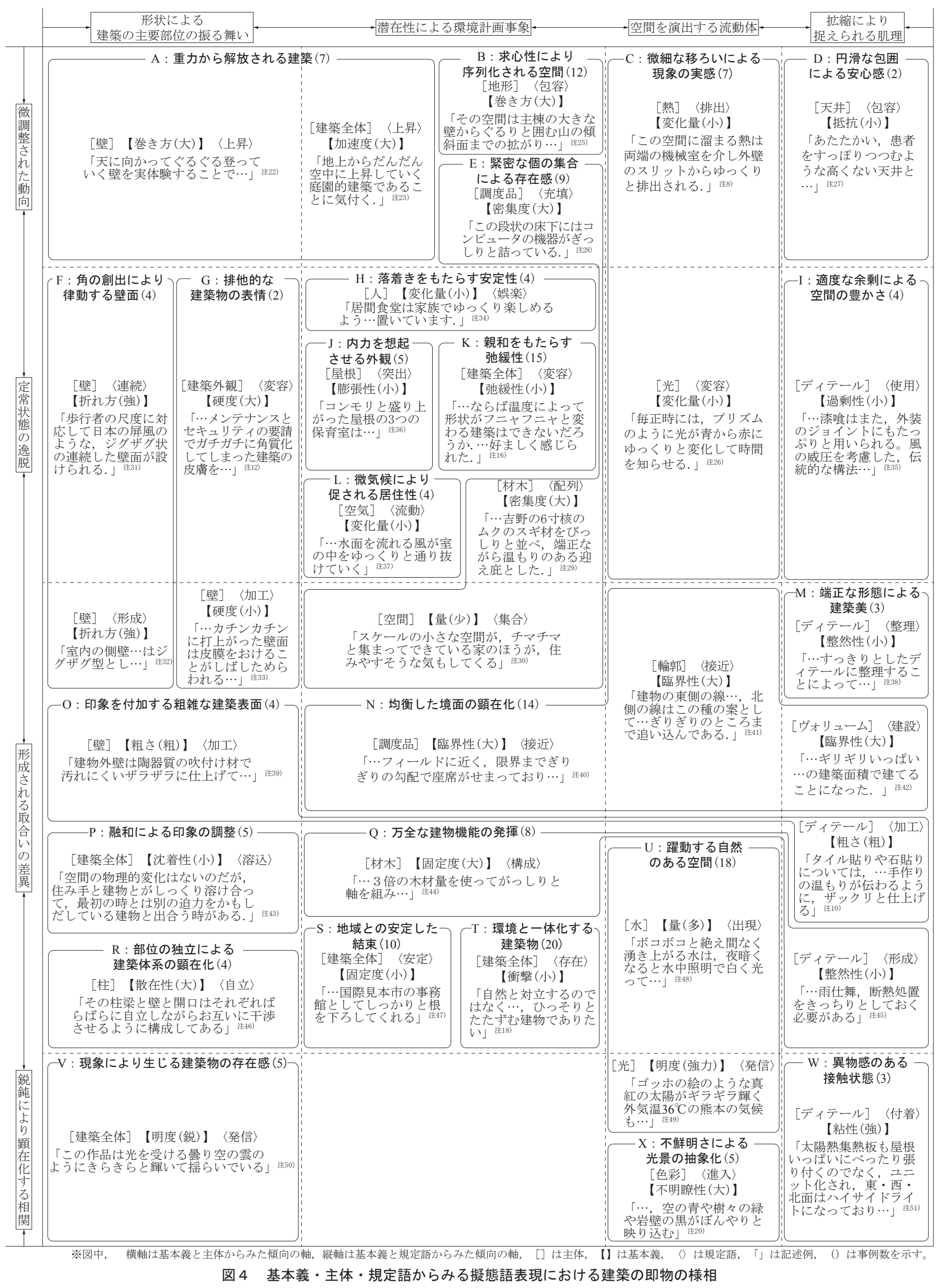


建築外観が与える視覚印象による嫌悪感などの建築物による人への 作用を暗示している。これらは人の知覚, 体験, 心理作用を促すも のとしての建築を構成する物体やその性状，及び空間の様相を表現 している。B， N，P， S，T，V，Xは，建築物の振る舞いによる外部 景観への指向性，位置や方向の指定による内包・外包関係，鋭鈍に よる前・背景化，形質の具合による合一化などの関係を示す。これ らは, 拮抗, 並置, 一体, 融合により, 建築物と周辺環境の物理的 な間柄を繊細に取り持っている。

以上より，設計者は擬態語を用いて建築物を描写寸る際，自身の 感性にもとづき，建築空間を構成する事物や現象に対して，その局 部や側面を顕在化させることで, 建築空間を構成する要素同士の関 係を相対化し，建築空間を複合的かつ概括的に捉えている。また， 建築空間内における人の物理的または心理的な挙動を暗示し，建築 空間に対して直接的かつ経験的な視座を導入することで，人の知覚 を介した建築物と人の関係を形成している。さらに，建築物の様相 を弛緩や緊張，律動や静止をもって抑揚づけることにより，建築物 とそれを取り巻く事象の間に相対関係を見出している。これは，建 築物の部分から全体およびその周辺の事象までの建築構成要素を連 続的な総体として捉えているといえる。つまり，一般概念を示寸言 葉による分節的な建築の思考とは異なり, 感性により捉えられる即 物間の関係の強弱に依拠したシームレスな思考によって, 建築の価 值が相対的に形成されていることが明らかになった。

\section{謝辞}

本稿を進めるにあたって，今枝良輔氏（University of Pennsylvania），藤 永麻友氏（旭化成ホームズ株式会社）, 野上将央氏（株式会社松田平田 設計）には，資料，論文作成にあたり多大なご協力を頂きました。文末 ではありますが，ここに記して感謝申し上げます。

注

注 1）言語音によって音や状態を表すことを言語学のうえで、音象徴という。 擬声語や擬態語は、一般言語と比較して、音声と指示対象の恣意性が 低く、音そのものがある特定のイメージを喚起させる（参考文献 4)。 日本語においては、外界の音を客観的に模した語彙を擬声語（擬音語）、 必ずしも音を伴わない事物の動きや状態を音声で象徴的に描写する語 彙を擬態語とし区別している（参考文献 5)。本研究では、擬態語のみ を扱っている。

注 2）本稿では，基本義，主体，規定語をキーコンテクストから抽出し，こ れらの語句の描写内容が示寸意味と照らし合わせて結論を導出してい る。そのため, 本文中の考察や図中における「」内の記述では，抽 出元となったキーコンテクストを考察内容に合わせて品詞の活用の変 換や文字の省略を行い例示しているが，文法上の表現を変えてもこれ による本稿の結論に関しての影響はないものと考える。

注 3）本稿では，擬態語の音韻の特徴を複数の文献（参考文献 4～10）を参 考に整理し，それに基づき基本義のカテゴリー分けを行っているが必 要な場合, 辞書に基づく用法も考慮している（表4)。

\section{表 4 擬態語の音韻の特徵}

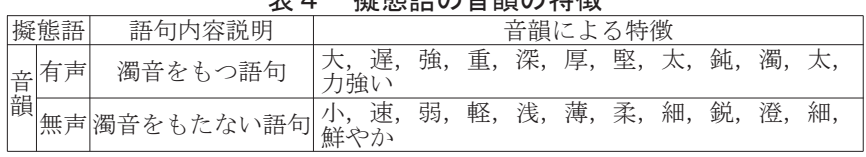

注 4）コレスポンデンス分析とは, 集計済みのクロス集計結果を使って, 行 の要素と列の要素と使い, それらの相関関係が最大になるように数量 化して行の要素と列の要素を多次元空間（散布図）に視覚化して表現
する分析方法を指す。類似度・関係性の強い要素同士は近くに，弱い 要素同士は遠くに布置される。ただし，相対的な位置関係であり，絶 対的なものではない。このとき，軸がクロス寸る原点付近に布置され る要素は比較的特徵が薄いと解釈できる。なお, 原点付近に布置する 要素の解釈には注意が必要である。原点付近の行は, 原点付近の列に 対する組み合わせの頻度が多いとは限らず，原点を離れた様々な方向 に布置されている場合がある。そのため原点付近に布置された行・列 を積極的に解釈寸ることは, 解釈の妥当性を低めることになり得る。

注 5) 河原一郎：長田邸, 新建築, p.231, 1979.2

注 6) 相田武文：P L 学園幼稚園, 新建築, p.229, 1974.1

注 7) 横河健 : 新川電機広島工場, 新建築, p.189, 1987.4

注 8) 清水建設 : パラマウントベッド テクニカルセンター, 新建築, p.126, 2007.4

注 9) 武井誠＋鍋島千恵／TNA：カタガラスの家，新建築，p.99，2008.11

注 10) 木村誠之助 : $K$ 証券葉山研修センター, 新建築, p.226, 1993.3

注 11) 渡辺豊和 : 龍神村民体育館, 新建築, p.212, 1987.6

注 12) 隈研吾 : オポジットハウス, 新建築, p.126, 2009.3

注 13) 三菱地所設計：三菱未来館@ e arth，新建築，p.185, 2004.12

注 14) 東孝光：さつき保育園, 新建築, p.243, 1973.8

注 15) 石黒由紀建築設計：B棟, 新建築, p.147, 2006.2

注 16) 隈研吾 : KRUG X KUMA $=\infty$ 〈無限大〉 KXK, 新建築, p.148, 2005.9

注 17) 槇文彦: 横浜市篠原地区センター・横浜市篠原地域ケアプラザ, 新建築, p.193, 1997.9

注 18) 竹中工務店 : 松蔭女子大学員大学大山ロッジ, 新建築, p.278, 1992.3

注 19) 矢吹昭良建築設計 佐藤商業建築研究所：グラスハウスうしかわ, 新建築, p.263, 1987.12

注 20) 渡瀬正記十永吉歩／設計室：〈まもとアートポリス「モクバン R2」球 磨のバンガロー, 新建築, p.185, 2009.9

注 21) コレスポンデンス分析において, 原点付近に布置された事例は, 原点 から離れた様々な方向の事例と組み合わさり, その組合せ数が均衡し た結果，原点付近に布置されている場合がある。そのため，原点付近 に布置された事例は, 他方のコレスポンデンス分析によって得られた 傾向の強い影響のもと，類型を構成する場合がある。この場合，構成 される類型は一方のコレスポンデンス分析の傾向の強い影響のもと, 他方のコレスポンデンス分析のいずれの傾向にもまたがる可能性があ るといえる。本稿では, このような類型の中には類型 $\mathrm{E}, \mathrm{Q}$ のように, 隣接する傾向を越えて括られる類型も含まれる。

注 22) 本稿では, 設計者の思考を総体的かつ相対的に読み解く研究として位 置付けられることを考慮し, 全体の中での特徵的な傾向のみられる事 例を考察する。そのために，該当するサンプル数が著しく少ない，極 めて特異な類型が生じないように, 類型を導出する基準を設定し, 24 種の類型を導出した。

注 23) 三菱地所設計 : 2006 年日本国際博覧会 企業パビリオンゾーンA 三 菱未来館@ earth, 新建築, p.169, 2005.5

注 24) 長谷川逸子：世界デザイン博覧会 インテリア館, 新建築, p.232, 1989.8

注 25) アトリエ $\mathrm{R}+$ アカデメイア建築研究所 : 林間劇場, 新建築, p.178, 1987.4

注 26) 近田玲子デザイン事務所 TIS \& PARTNERS：光のプリズム (川口公 園エレベータシャフト上屋), 新建築, p.260, 1994.4

注 27) 倉敷建築事務所 : 愛染橋病院, 新建築, p.153, 1965.3

注 28) 鹿島建設 : 三洋証券本社別館, 新建築, p.252, 1988.7

注 29) 渡辺明設計：千本松沼津俱楽部, 新建築, p.65, 2008.10

注 30) 石井和紘 : 児玉邸, 新建築, p.264, 1980.8

注 31) 磯崎新 : ラ・コルーニャ人間科学館, 新建築, p.120, 1995.7

注 32) 谷口吉郎: 慶応義塾幼稚舎講堂, 新建築, p.147, 1964.7

注 33) 山添建築設計 : カトリック八戸塩町教会, 新建築, p.189, 1984.4

注 34) 竹中工務店: 勾配屋根とスキップフロアーの住宅, 新建築, p.127, 1962.5

注 35) 渡辺明：二期俱楽部，新建築， p.236，1987.1

注 36) 村山建築設計 : 東江幼稚園, 新建築, p.204, 1995.4

注 37) 黒川紀章 : 吉備町役場, 新建築, p.125, 1995.12

注 38) 前川建築設計 : 専修寺納骨堂, 新建築, p.166, 1999.2 
注 39) 宮脇檀 : BOX-A QUARTER CIRCLE, 新建築, p.230, 1977.2

注 40) 黒川紀章 : 豊田スタジアム, 新建築, p.203, 2001.9

注 41) 早大安藤研究室: 第四大島小学校, 新建築, p.10, 1958.5

注 42) 宮脇檀: グリーンボックスハウス\# 2, 新建築, p.208, 1973.2

注 43) 深谷俊則 : トラスの家, 新建築, p.240, 1977.2

注 44) アトリエR：静照院，新建築，p.181，1987.4

注 45) 創設計：北新在家の家，新建築，p.298, 1984.8

注 46) 長谷川逸子 : 徳丸小児科, 新建築, p.184, 1979.10

注 47) 清水建設 : 東京国際見本市協会, 新建築, p.189, 1966.12

注 48) 葉祥栄 : A C T 6 , 新建築, p.167, 1985.10

注 49) 野中建築事務所 : 野中建築事務所, 新建築, p.177, 1965.9

注 50) 隈研吾 : 宝積寺駅グリーンシェルター, 新建築, p.81, 2006.7

注 51) 石井和紘 : 直島町民体育館・武道館, 新建築, p.266, 1977.1

参考文献

1）宇野真明, デワンカー・バート：空間を表現する擬態語に関する研究 一設計経験者と非経験者の比較一, 日本建築学会九州支部研究報告集. 計画系, 第 50 号, pp.133-136, 2011.3

2）秋田剛, 古賀誉章, 佐野奈緒子, 辻村壮平, 石黒恭平 : 擬態語 - 擬音 語を用いた環境表現に関する基礎的研究, 日本建築学会大会学術講演 梗概集, D-1 分冊, pp.183-184, 2011.7

3) 新建築社: 新建築, 1950.1-2010.12

4) Shoko Saito Hamano: The Sound-Symbolic System of Japanese, Thesis (Ph. D.) University of Florida, 1986.5

5）吉井宏 : 空間認識の方法と発達について—その（2）オノマトペの発生 と構造, 美術教育学, 美術科教育学会誌, 第 5 号, pp.89-99, 1983.12

6）田島毓堂, 丹羽一弥編: 日本語論究〈3〉現代日本語の研究, 和泉書院, 1992.12

7）柴田武：日本語はおもしろい，岩波書店，1995.1

8）熟田清一：「ぐずぐず」の理由, 角川学芸出版, 2011.8

9）阿力田稔子, 星野和子 : 擬音語・擬態語使い方辞典一正しい意味と用 法がすぐわかる, 創拓社, 第 2 版, 1995.10

10）小野正弘：擬音語・擬態語 4500 日本語オノマトペ辞典, 小学館, 2007.10 


\title{
MATERIAL ASPECTS OF ARCHITECTURE AND MIMETIC WORD EXPRESSION IN TEXT DESCRIPTION OF BUILDINGS
}

\author{
Hiroyuki SHINOHARA*, Keisuke KITAGAWA** and Sho TAHARA*** \\ * Doctor Course Student, Graduate School of Engineering, Nagoya Institute of Technology, M. Arch. \\ ** Assoc. Prof., Tsukuri College, Graduate School of Engineering, Nagoya Institute of Technology, Dr. Eng. \\ *** Sumitomo Forestry Co., Ltd., M. Eng.
}

The text description of building by mimetic words is a frequently used form of communication for Japanese architects to express their architectural design intent. The mimetic words describe a material building vividly and sensually as if it gains its own life and express connotative meaning of architecture that the architect imbues through the depicted building posture and gesture. The objective of this paper is to identify material aspects of architecture rhetorically characterized by mimetic word expressions used in the explanation of works of architecture through the text description of buildings in a monthly Japanese architecture magazine, Shinkenchiku.

The flow of this research is as below:

1. Extract sentences which contain mimetic word expression used by architects to explain their design from Shinkenchiku published during 1950 - 2010.

2. Extract Subjects, Mimetic words and Regulating verbs. Subject refers to a building itself or a physical constituent of architecture depicted by a mimetic word in the sentence. Mimetic word is defined as a sound-symbolic word that describes Subject in the sentence. Regulating verb is a verb of the Subject, a word grammatically forming the main part of the predicate of the sentence, to describe an action, state, or occurrence of the Subject together with the mimetic word.

3. Classify mimetic words by the sound-symbolic meaning, then cross-reference them with subjects and regulating verbs respectively to analyze and derive semantic tendencies when they are combined.

4. Map out material aspects of architecture rhetorically characterized by mimetic word expression with a matrix in which the horizontal axis is the tendency of meaning by the combination of the mimetic words and the subjects, and the vertical axis is that of the mimetic words and the regulating verbs.

As a result, four semantic tendencies are found from the analysis of the combination of mimetic words and subjects: (1) Primary building component's behavioral gesture characterized by the visual configuration, (2) Environmental design element characterized by the elastic appearance, (3) Fluid environmental element that relates to the production of a space, and (4) From a part to the whole of a building grasped as grain by zooming. From the analysis of combination of the mimetic words and the regulating verbs, four semantic tendencies are found: (A) Fine-tuned movement, (B) Deviation from a steady state, (C) Manipulated joint, and (D) Correlation actualized by sharpness. In the end, 24 typical material aspects of architecture expressed in mimetic word descriptions are identified through the mapping.

In summary, with mimetic word expressions, architects characterize the quality of architecture which is difficult to measure and describe by a single conceptual term with their sensibility through the sound-symbolic word in the text description of buildings. It recognizes architecture as a dynamic conglomeration of multiple assets and meaning ascribed to the material properties of the building constituents by assuming a human body positioned within architecture through which embraces real environments in and around which the building is set. Through the research of the mimetic word expressions, this paper revealed a lateral thinking of architects enabling the production of continuous and inclusive architecture of everyday. 